\title{
Positive Deviance Behavior in the Low Economic Status Family with Non-stunting Incidence in Sleman Regency, Yogyakarta, Indonesia
}

\author{
Kartika Setyaningsih Sunardi, Evi Martha* \\ Department of Health Education and Behavioral Sciences, Faculty of Public Health, Universitas Indonesia, Depok, 16424, Indonesia
}

Received July 1, 2021; Revised October 20, 2021; Accepted November 11, 2021

\section{Cite This Paper in the following Citation Styles}

(a): [1] Kartika Setyaningsih Sunardi, Evi Martha, "Positive Deviance Behavior in the Low Economic Status Family with Non-stunting Incidence in Sleman Regency, Yogyakarta, Indonesia, "Universal Journal of Public Health, Vol. 9, No. 6, pp. 353 - 359, 2021. DOI: 10.13189/ujph.2021.090601.

(b): Kartika Setyaningsih Sunardi, Evi Martha (2021). Positive Deviance Behavior in the Low Economic Status Family with Non-stunting Incidence in Sleman Regency, Yogyakarta, Indonesia. Universal Journal of Public Health 9(6), 353 359. DOI: 10.13189/ujph.2021.090601.

Copyright $\subseteq 2021$ by authors, all rights reserved. Authors agree that this article remains permanently open access under the terms of the Creative Commons Attribution License 4.0 International License

\begin{abstract}
Positive deviance is an uncommon condition where the behavior or activities of a person or group in a population can unconsciously be a protective factor for a problem. Positive deviance behavior can occur in Sleman Regency with a stunting incidence rate of $11 \%$, because it still has a sub-district with a relatively higher incidence of stunting than the average of Sleman Regency. This study discusses the analysis of feeding behavior, parenting behavior, hygiene behavior, and health care behavior as positive deviance (PD) behaviors in low economic status families with non-stunting incidence in Sleman Regency, Yogyakarta. This study is a qualitative study conducted in Sendangarum Village, Minggir District, Sleman Regency in the period between June and July 2020 for low economic status families who have children aged 1-2 years with not stunting incidence. The results of this study indicate positive deviance behavior in families with low economic status with non-stunting namely feeding behavior, parenting behavior, and hygiene behavior. The results of this study were important to analyzed PD behavior in Sendangarum Village, so that the officials could make an intervention by considering the findings to prevent stunting. The conclusion of this study found that positive deviance behavior in families with low economic status with non-stunting incidence were: 1) feeding behavior with a frequency of three times a day for main meals and side meals, 2) food ingredients consumed by children with good nutritional value with main meals a
\end{abstract}

four-star menu and a snack, 3) the quantity of time parents spend with their children, 4) the role of parents when with children, 5) joint activities before bedtime, and 6) the behavior of maintaining the child's body hygiene, such as brushing teeth before bed.

Keywords Positive Deviance Behavior, Stunting, Low Economic Families

\section{Introduction}

Stunting is a major public health problem, which has now become an international concern due to its impact on children globally, both in the short and long term. Stunting is also associated with poor cognition, quality of education, performance and productivity [1]. The World Health Organization mentions eight major points of the causes of stunting, such as problems of nutritional quality, safety of food and water sources, characteristics of mothers, home environmental conditions, infectious diseases, parenting behavior, exclusive breastfeeding, complementary feeding (MP-ASI). In addition, there are six things that can indirectly influence the incidence of stunting, namely the political economy; agriculture and food systems; water, sanitation and environment; health and health services; as well as social and cultural 
condition [2].

The prevalence of stunting in the world between 2000 and 2018 has decreased from 198.2 million to 149 million; however, WHO has a target to reduce stunting that must be met by $40 \%$ by 2025 [2]. In 2018, more than half of children under the age of 5 years who were stunted lived in Asia, namely 55\%. Southeast Asia experienced a decrease in prevalence from 2000 by $38.4 \%$ to $25 \%$ in 2018. However, this figure is still in the high category, especially when compared to the percentage of stunting in the world in 2018 of $21.9 \%$. Southeast Asia also has the second highest stunting prevalence in the Asian continent after South Asia [3].

In 2018 the prevalence of stunting in Indonesia was $36.4 \%$. Indonesia is ranked the fifth highest stunting prevalence in the Asian continent. Based on this data, Indonesia is also in the second rank in Southeast Asia after Laos [4]. The province with the highest prevalence of stunting in Indonesia is East Nusa Tenggara at $42.6 \%$, while the three provinces with the lowest prevalence of stunting are the Special Capital Region of Jakarta at $17.7 \%$, followed by Yogyakarta Special Region in second place and Bali in third place [5]. Based on previous research, one of the determinants that influence the incidence of stunting is low family income [6]. Other studies have also proven that family income is one of the factors associated with stunting [7]. Low family income will determine the availability of food so that it can affect the fulfillment of family nutrition. If nutritional needs are not met properly, the possibility of stunting will be even greater [8].

The Special Region of Yogyakarta (DIY) based on data from Basic Health Research (Riskesdas) in 2018, became the second lowest province for stunting after the Special Capital Region of Jakarta nationally [5]. However, it is inversely proportional to economic status, where D.I Yogyakarta is the poorest province on the island of Java. Nationally, D.I Yogyakarta is ranked as the 12th lowest economy [9]. Yogyakarta Special Region Province administratively consists of one municipality and four districts, namely: 1) Yogyakarta City, 2) Bantul Regency, 3) Kulon Progo Regency, 4) Gunung kidul Regency, and 5) Sleman Regency. Sleman Regency is a district in DIY which has an incidence rate of stunting cases of $11 \%$ [10].

The low economic status of the people in Sleman Regency can be seen from the data from the Central Statistics Agency of Yogyakarta Province D.I. In 2019 the Poverty Line Limit (Garis Kemiskinan/GK) for Sleman Regency is Indonesian Rupiah (IDR). 382,868 where this figure has increased from IDR 370,127 in 2018 [11]. However, the Poverty Line Limit in Sleman Regency is still below the average national Poverty Line Limit, which is IDR 425,250 per capita per month in 2019 [12]. The Poverty Line Limit is the sum of the Food Poverty Line (Garis Kemiskinan Makanan) and the Non-Food Poverty
Line (Garis Kemiskinan Non Makanan). People who have an average expenditure per capita per month below the Poverty Line Limit are categorized as poor [11].

Economic status is usually seen from three aspects, those are education, employment, and income, although sometimes in some measures the socio-economic status can only cover two of the three. This is because the relationship between the three, for example if education is low, it is possible for individuals in a family to have inadequate jobs so that it will be directly proportional to their income. The possibility of a low economic status of an individual or a family can also be seen only from indicators of education and income or employment and income [13].

From the results of research that has been conducted on the factors that influence stunting, it is inversely proportional to the situation in Sleman Regency where the average per capita income of the people is still low. This is a distorted condition which can be said as Positive Deviance or positive deviation, if a family is found with a low economic condition but does not have stunting children in the middle of society. Whereas if you look at the existing data, there are many stunting incidents in that area. Positive deviance is an uncommon condition where the behavior or activities of a person or group in a population can unconsciously be a protective factor for a problem.

Positive deviance is closely related to local wisdom, so it is said that solutions to existing problems can be found within the community itself without any outside intervention [14]. Positive deviance behavior can occur in Sleman Regency with a stunting incidence rate of $11 \%$, because it still has a sub-district with a relatively higher incidence of stunting than the average of Sleman Regency. Based on the results of a preliminary study conducted at the Sleman District Health Office on March 30, 2020, Minggir District is a sub-district in Sleman Regency with the most incidence of stunting, namely $15.76 \%$. If you look deeper, Minggir District has the village with the most incidence of stunting, which is $18.48 \%$ in Sendangarum Village. This figure is relatively much higher when compared to the average prevalence of stunting in DI Yogyakarta, which is $12.37 \%$ [10].

The four main behaviors of PD behavior are; 1) feeding behavior, 2) parenting behavior, 3) hygiene behavior, and 4) health care behavior. PD behavior is found when there are behaviors that are usually carried out by PD families and not by Non PD families. If the behavior usually carried out by PD families is the same as the general behavior, then it cannot be said to be PD behavior. The aim of this study is to discuss the analysis of feeding behavior, parenting behavior, hygiene behavior, and health care behavior as positive deviance (PD) behavior in low economic status families with non-stunting incidence in Sleman Regency, Yogyakarta. 


\section{Materials and Methods}

This study uses a qualitative research method using the phenomenology approach. This research was conducted in Sendangarum Village, Minggir District, Sleman Regency with a time span between June to July 2020. The principles used in this study were suitability and adequacy with purposive sampling technique. Purposive sampling technique was carried out to determine which informants would be taken according to the needs of the research topic, therefore the researchers made inclusion and exclusion criteria.

The inclusion criteria of this study: 1) come from families with low economic status. Low economic status based on referrals from health cadres according to the criteria of being poor in the community and checking again by asking local community leaders, 2) having children aged 1-2 years with height/age -2 Standard Deviation, are not sick and have increased weight three consecutive months as seen from data from health cadres and health center, 3) live with the mother, and 4) are biological children. The exclusion criteria of this study were not willing to be research informants and under five years old with physical and mental disabilities.

The status of not stunting was seen from the data available at Minggir Community Health Center. The informants of this study were the father and mother (husband and wife) who came from families who met the criteria inclusion and exclusion of four families. As a comparison of PD behavior, research will also be conducted on families with low economic status of two families with stunting children who are Non PD. This study uses recorder to record the interview.

\section{Data Analysis}

The content of the tape-recorded interview was fully transcribed into verbatim transcription. Data coding is done manually with labeling the field notes as well as the results of data transcripts while cross-checking the voice recordings. Data coding is done according to the variables taken. The preliminary overview analysis is carried out by identifying the state of the community's economic status, identifying natural resources utilized by the community, and identifying PD behavior in terms of providing food, care, hygiene and health services.

The second analysis was carried out by analyzing the results of the interview. In this analysis, the main domains were retranslated into more detail, for example, such as the behavior of feeding which is retranslated, such as what kind of food is given, how frequent and what size is given. This analysis makes it easy for researchers to know in depth the domain under study. The third step, the researcher carried out the analysis by comparing the results of the data collection that had been done. The results of the interviews and secondary data were collected and analyzed to confirm one result with another. This analysis was carried out by means of source triangulation, namely the validity of the qualitative research itself. The final analysis was carried out by looking at the relationship between the domains and the relationship between all parts of the variable under study. In this analysis, the final conclusions are obtained from the results of the research that has been done.

\section{Results}

Positive deviance family behavior will be obtained by comparing the behavior between families with stunting and non-stunting children. Families with non-stunting children are said to be positive deviance (PD families), while families with stunted children are Non Positive Deviance families (Non PD families). This study took six families as the main informants, four PD families and two Non PD families. Four PD families were taken to find out whether they did PD behavior, while as a comparison; two families without PD were taken. PD behavior is found when there are behaviors that are usually carried out by PD families and not by Non PD families. If the behavior usually carried out by PD families is the same as the general behavior, then it cannot be said to be PD behavior.

The six families that were conducted in-depth interviews were low-income families who lived in six different hamlets. The PD 1 family living in Daratan II Village was a family with the father as the backbone of the family who worked precarious jobs. This family opened a small grocery shop at home and also sells coconuts he harvested only from the six trees behind his house. Apart from the coconut trees behind the house, they also plant aloe vera, moringa trees and tintir castor trees or what the people of Sendangarum Village call Iodine Trees. Behind the house there is also a chicken coop and a 2 × 2 meter fish pond. This family who has two children aged 6 years and 19 months has a house surrounded by gardens because it is located at the end of the village. Next to the house, you can see a vast expanse of rice fields.

PD 2 family is a family who lives in Soromintan Village. This family which has two children aged 7 years and 15 months has a house in the middle of a hamlet. This house which is still tiled floor and brick walls has a fish pond measuring approximately $3 \times 2$ meters which is filled with tilapia and catfish on the left side of the house. Around the pond you can also find banana trees, papaya trees and moringa trees which are often used as daily consumption for this family.

PD 3 family is a family that has one 13 year old boy and one 14 month old girl. The family who lives with their grandmother has a house on the side of the road in Ngijon Village. The floor of the house is mostly ceramic, only a little area left in the kitchen is still tile. The father 
of this family is a smoker so there is a long chair beside the house where he usually sits to smoke. This family also owns Rambutan trees, Papaya trees, Moringa trees and Tintir Jatropha trees which are planted by themselves next to the house, so that when needed they are easy to collect.

PD 4 family is the one who just has a 23 month old daughter. The house of this family has a cement floor which is still dusty in the living room, but has tiles in the bedroom and kitchen area. The bedroom area which is also used as a family room is one area with a kitchen that is about $4 \times 5$ meters in size. This family has a hobby of fishing in the river because their mother, who comes from Palembang, has been accustomed to fishing by fishing in the Musi River since childhood. Incidentally, the house they live in is only about 700 meters from the river in Sanan Village. His father also likes to go fishing so that in a week they can spend three to four times fishing.

A Non PD 1 family is a family who lives in Daratan 3 Village. This family has a house near the river and is about 17 × 6 meters in size which is filled with 10 people. This house is divided into three large rooms for the three families in it. Each area of the room is separated by a wall but has a door that connects one room to another. The lack of ventilation has made the air circulation less smooth in the room inhabited by this Non PD 1 family. Behind the house is a dark bamboo garden before the river. The father of this family is a retiree who had long migrated to Sorong, Papua. He has been married and has 3 big daughters. His first wife died, then he returned to his hometown and married his current wife.

This family is blessed with a one year old son. Non PD 2 families are families who live in Toglengan Village. The father of this family is a trader who has to go to the market every day at $05.00 \mathrm{am}$. Her mother is an honorarium teacher who teaches at an elementary school not far from home. The family lives with her father's parents. When his father and mother go to work, their first child, who is 22 months old, will stay at home with his grandparents. Her grandfather opened a small workshop in front of the house. The environment in his house is a little dirty because he raises chickens that roam freely beside and in front of the house. Plus the location adjacent to other houses makes this house feel stuffy and damp.

\section{Feeding Behavior}

Profile of the six both PD families and Non PD families are associated with the behaviors that families usually do with regard to children. Referring to the conceptual framework, the four main behaviors of PD behavior will be translated into several important points. Feeding behavior is seen from how breastfeeding is to children, how the habits of giving food or complementary foods are to children and what food ingredients are consumed by children. Out of three points of feeding behavior, two of them were PD behavior. Breastfeeding behavior was not found as PD behavior because both PD families and Non PD families were give exclusive breastfeeding for their children. They even breastfeed their children until their children turned two years old.

In this study, the habits of giving food or complementary foods to children was found as PD behavior because PD families tend to provide main meals and snacks three times a day, which have four star menu and great nutritional value. While the Non PD families only provide main meals and snacks twice a day which have low nutrition.

This study found another PD behavior in feeding behavior aspect was food ingredients that consumed by children. PD families usually have various vegetables which are nutritious for their main meal, such as moringa leaf soup, tempeh, tofu, tilapia, and catfish. As for snacks, PD families also provide nutritious snacks for their children such as red bean porridge, green bean porridge, papaya, and banana. Whereas Non PD families only provide low nutrition main meals and snacks such as nugget, soy sauce, fast food, and fried food.

\section{Parenting Behavior}

Parenting behavior is seen from how the role of the parents is when with the child, and what parents usually do with the child before going to bed. This study found that PD families have intelligence or motoric training activities with their children because they usually do interactive activities such as fishing and two way communication. While Non PD families just let their children watch television or play with handphone. We also found that children of Non PD families were raised by other family member because the mother is working.

In this study, activities carry out by the family before going bed was found as PD behavior. PD families will have interactive activities with their children before going bed such as telling story, singing, and praying together. Whereas children of Non PD families only watching television before going to bed.

\section{Hygiene Behavior}

Hygiene behavior is seen from the cleanliness of the child's body and the cleanliness of the environment around the child. This study found that PD behavior in hygiene behavior aspects was only the habit of brushing tooth before going to bed. PD families teach their children to brush their tooth when taking a bath and before going to bed. While the children of Non PD families only brush their tooth when taking a bath.

We found that both PD families and Non PD families have taken care their child's cleanliness with ensuring that their child take a bath minimal twice a day, change clothes when wet the bed, use slipper when go out. As for the cleanliness of the environment around the child, both 
families also keep their environment clean with having trash bin, using toilet, and having septic tank.

\section{Health Care Behavior}

Health care behavior is seen from immunization behavior, participation in health post activities, behavior when the child has a fever, cough or cold, and behavior when the child has minor injuries when he falls or is certain of something. This study found that there are no PD behaviors in the health care behavior aspect. This is because there are no different behaviors in both PD families and Non PD families. They both not decline immunization program for their child, even have complete immunization for their child. They also regularly participate in health post activities. Both families know how to treat minor injuries.

\section{Discussion}

Based on the results of the research that has been done, there are four PD behaviors. These four behaviors are common behaviors carried out by PD families but not by Non PD families. The results of this search also indicate that the PD behavior that is found is not a common behavior. Feeding behavior that is included in PD behavior is the frequency of feeding children three times a day for main meals and snacks with nutritional ingredients, respectively. Parenting behavior which is PD behavior, those are the quality and quantity of activities of parents with children and what activities are carried out before bed. Hygiene behavior included in PD behavior was brushing children's teeth before going to bed.

Of all these PD findings, divided into two behaviors, those are specific behavior and general behavior. Specific behavior is behavior that can only be applied to the area of this research area, namely in Sendangarum Village such as feeding behavior in terms of snack food, namely red bean porridge and green bean porridge because not all regions can apply it, while other behaviors can be categorized as general behavior, namely the frequency of feeding three times a day each for main meals and snacks with nutritional ingredients as well as the quality and quantity of activities that parents do with their children and what activities are done before bedtime.

\section{Feeding Behavior}

Feeding behavior or complementary food of breast milk and Food Ingredients for Children The behavior of PD, which is usually done by PD families in providing food to their children, is that children are given main food and snacks each three times a day. Not only the frequency of giving, another thing that makes this behavior a PD behavior is where the main food and side food given to children provide balanced nutrition. The nutrition sector at Minggir Community Health Center has educated and trained cadres to be able to prepare food with a four-star menu, so that cadres can inform mothers at the health post to provide food to their children according to recommendations. The Ministry of Health issued a guideline as an example of a four-star menu that mothers should serve for complementary feeding (MPASI). The four star menu includes a source of carbohydrates, vegetable protein, animal protein and vegetables [16].

PD 1 families usually complement their children's main meals with rice as a source of carbohydrates, tofu or tempeh as a source of vegetable protein, eggs or fish as a source of animal protein and clear vegetables of Moringa leaves as a source of vegetables. The PD 3 family also used to provide clear vegetables with Moringa leaves because they planted Moringa trees behind their house. The benefits of moringa leaves were known by the PD 1 family mother from reading articles on the internet, while the PD 3 mother found out from the information provided by the health post cadres. The cadre informed that Moringa leaves are efficacious to prevent stunting in children. Three of the four PD families studied have their own fish ponds which are devoted to family consumption.

The types of fish that are kept by the three families for consumption are tilapia and catfish. Another PD family has a habit of fishing by fishing in the river behind his house. In addition to the main food that is given, the family also provides a snack with good nutrition. The PD 1 family usually provides a snack in the form of red beans which is processed into porridge and is the favorite snack for their children. The PD 2 family usually provides a snack for his son is green bean porridge. Sometimes the PD 4 family also gave the same menu, namely green bean porridge, sometimes also given a snack in the form of marrow porridge or pearl porridge. Another good nutritional snack usually given to children, namely fruits. PD 2 family used to give banana and papaya fruit from their own garden, while PD 3 family planted rambutan and papaya trees for consumption. The four PD families who were conducted in-depth interviews had the behavior not to accustom their children to eating fast food (fast food) and also packaged food.

\section{Parenting Behavior}

The intensity of togetherness between parents and children becomes less qualified if the parents do not have enough time to spend with the child. Sometimes even though they are on the side of the child, if the activities carried out do not train the child's motor and cognitive intelligence, the togetherness is not of good quality. The role of parents is the determining factor primary in the quantity and quality of activities that support child development. In general, families with children aged 1-2 years have the same parenting problems, both working 
mothers and housewives. PD behavior in this case that was found was the habit before going to sleep.

Guidelines for parenting behavior towards children have been issued by the Ministry of Education and Culture of the Republic of Indonesia. This parenting behavior guide is called positive parenting, where one of the activities parents can do with their children, among others, is to invite children to guess the names of objects on colored pictures, such as books on the names of fruits or objects around the child [15]. PD 2 families used to do activities such as telling stories about what the children did every day. Children are trained to be open and free to tell stories with parents from an early age in the hope that this behavior will become a habit until the child grows up. This storytelling habit can also strengthen the bonding or closeness of parents to have other habits before going to bed, namely by getting used to inviting and teaching children to go to school. Parents say that the purpose of teaching children to practice prayer is so that children become individuals who know and love their Prophet from childhood.

\section{Hygiene Behavior}

PD families also have the habit of brushing their children's teeth before going to bed apart from brushing their teeth when they take a bath. This habit is actually a common practice for parents, which is then applied to children to become a habit for children. According to previous research, brushing teeth before bed is an indicator of Clean and Healthy Life Style (PHBS) which must also be applied to children. PHBS is associated with the incidence of diarrhea in children [10]. Long-term diarrhea, if not treated promptly, will result in malnutrition in children. Previous research has shown that approximately $72.7 \%$ of children who are stunted less than 59 months of age often experience diarrhea [11]. PD 2 families have unique and positive behaviors in maintaining children's oral and dental hygiene. Both parents of the PD 2 family have familiarized their children with cleaning their mouths even before the child's teeth grow. Usually mothers only clean the child's tongue and palate with a wet cloth slowly so that the child sleeps in a clean mouth condition. Until now the habit of cleaning the mouth is still routine before bed. Now the child is 23 months old and brushing teeth is an activity that he never misses at night, even the child will ask if his parents forget to invite him to brush his teeth before going to bed. The PD 4 family also shared that brushing their teeth before going to bed was a habit that both parents did. The father of the PD 4 family said that children would easily imitate what their parents did, so that naturally this behavior in brushing teeth before going to bed became a habit for children. Children will be willing to do a behavior that has become a habit without even being asked by the parents.

\section{Conclusion}

Positive deviance behavior in families with low economic status with non-stunting incidence were; 1) feeding behavior with a frequency of three times a day for main meals and side meals, 2) food ingredients consumed by children with good nutritional value with main meals a four-star menu and a snack, 3) the quantity of time parents spend with their children, 4) the role of parents when with children, 5) joint activities before bedtime, and 6) the behavior of maintaining the child's body hygiene such as brushing teeth before bed.

\section{REFERENCES}

[1] Onis M de, Branca F, "Childhood stunting: A global perspective", Matern Child Nutr, vol. 12, pp. 12-26, 2016. DOI: $10.1111 / \mathrm{mcn} .12231$

[2] UNICEF, "Improving Child Nutrition: The achievable imperative for global progress", UNICEF, https://data.unicef.org/resources/improving-child-nutritionthe-achievable-imperative-for-global-progress/ (accessed July 20, 2019).

[3] UNICEF, WHO, and The World Bank, "Levels and trends in child malnutrition: Key findings of the 2018 edition of the joint child malnutrition estimates", World Health Organization, https://www.who.int/nutgrowthdb/2018-jme -brochure.pdf (accessed July 1, 2019).

[4] UNICEF, "Scaling up nutrition around the world in 2017-2018", UNICEF, https://scalingupnutrition.org/wp-c ontent/uploads/2018/11/SUN_Report_EN_2018_Region_ East_and_Southern_Africa.pdf (accessed July 16, 2019).

[5] Satriawan E, "National strategy for the acceleration of stunting prevention 2018-2024", TNP2K, http://www.tnp2 k.go.id/filemanager/files/Rakornis\%202018/Sesi\%201_01 _RakorStuntingTNP2K_Stranas_22Nov2018.pdf (accessed July 28, 2019).

[6] Lestari W, Margawati A, Rahfiludin MZ, "Risk factors for stunting in children aged 6-24 months in the Penanggalan Sub-District, Subulussalam City, Aceh Province", J Gizi Indones, vol. 3, pp. 37-45. 2014. DOI: 10.14710/jgi.3.1.126-134

[7] Setiawan Eko, Rizanda Machmud M, "Factors related to the incidence of stunting in children aged 24-59 months in the work area of the Andalas Puskesmas, Padang Timur District, Padang City, 2018", J Health Andalas, vol. 7, pp. 275-84, 2018. DOI: $10.25077 /$ jka.v7i2.813

[8] Kusumawati E, Rahardjo S, Sari HP, "Model for controlling risk factors for stunting in children under three years of age", J Public Health, vol. 9, pp. 249-56, 2013. DOI: 10.21109/kesmas.v9i3.572

[9] Jayani DW, "Which province has the highest poverty rate?", Katadata, https://databoks.katadata.co.id/datapublish/2019/ 07/16/provinsi-mana-yang-memiliki-angka-kemiskinan-ter besar (accessed July 1, 2019). 
[10] DIY Provincial Health Office, "Health profile of D.I. Yogyakarta in 2018", Dinkes Provinsi Jogja, https://www.dinkes.jogjaprov.go.id/download/download/2 7 (accessed Jan. 5, 2019).

[11] Provincial Statistics Agency D.I. Yogyakarta, "Table of percentage of poor population by Province D.I. Yogyakarta in 2018", BPS Yogyakarta, https://yogyakarta.bps.go.id/sit e/resultTab (accessed Jan. 9, 2019).

[12] Central Bureau of Statistics, "Poverty and inequality", BPS, https://www.bps.go.id/subject/23/kemoverty-dan-ketamaan .html\#subjekViewTab1 (accessed Jan. 12, 2019).

[13] Mayer S., "The influence of parental income on children's outcomes", Researchgate, https://www.researchgate.net/pu
blication/239574341_The_Influence_of_Parental_Income_ on_Children's_Outcomes (accessed Jan. 29, 2019).

[14] Positive Deviance Collaboration, "What is positive deviance?", Positive Deviance Org, https://positivedevianc e.org/ (accessed July 8, 2019).

[15] Sukiman, "Parent education series: Safe internet", Repositori, http://repositori.kemdikbud.go.id/9739/1/Intern et\%20Aman\%20Revisi\%2014.pdf (accessed July 20, 2019).

[16] Ministry of Health RI, "Four star menu for complementary feeding 2014”, Citradenali, http://citradenali.info/wp-conte nt/uploads/2018/06/Menu-MP-ASI-4-BintangPGS.pdf (accessed Jan. 7, 2019). 